\title{
Autumn
}

\section{IN THE VALLEY OF THE ASSINIBOINE}

By John E. Nixon, Wauchope

Not one false note in all the eye perceives,

No jarring contrast and no line untrue,

From that wide arch of opalescent blue

Down to the valley where the river weaves

Its winding course and in far distant cleaves

The lessening hills. This scene the Indian knew

In long dead autumns when October grew

Like multitudes of red and golden leaves.

Surely a spirit harbors in this place,

Haunting lost paths and hearthstones overthrown,

Making dim pasts to our tomorrows join -

Some lingering echo of that vanished race,

Too soon forgotten and too late unknown,

That whispers in the word Assiniboine.

\section{Cranberry Hike}

By RAY PETERSON, Tofield, Alberta

It was a grey, still day, with occasional bursts of sunlight smiling through the low clouds. Micheal and Colin trotted happily along beside us as Kathryn and I started off towards the muskegs. The third week in October is a bit late to pick cranberries, perhaps, but the notion had struck us and off we went.

The countryside, already stripped of its gay autumn colors, was clothed in warm browns and greys, trimmed here and there with the hardy greens of short, second-growth grasses, and the old-gold of a few remaining willow leaves. The water in a large slough we passed was a dark mirror blue-grey, cracked in the centre by the wake of a cruising muskrat. As we crunched through a long stretch of woodland, Kathryn scuffed a foot in the thick covering of fallen leaves. "It's like walking on a thick carpet of cornflakes," she said.

We ducked through a ring of tangled willows and entered a small muskeg. It was a pretty place with its humps of Labrador Tea, the small clumps of white birch saplin Clustered on small-leafed plants $y$ the small, richly-red fruit of the I Ground Cranberry. It was lur time. We perched on mounds holstered with spagnum moss, ate the sandwiches we had broug How few they seemed, and how gi they tasted, especially the che ones garnished with a liberal sprir ling of the tangy, juicy cranberr

After picking a few quarts of small, bright berries, we crossed a larger muskeg. Here we found larger fruit of the Swamp or $H$; Cranberry. Its fruit, often mott 1 and speckled before fully ripe, $h$ the ground on fine threads and gro; in assorted shapes, spherical, oblo, and pendant-shaped.

Scattered over the muskeg w? great quantities of dried mushroo: too brown and shrivelled to be ide ified. Large clumps of grey licl 1 dotted the muskeg. Here too, w 3 a few clusters of tiny, dark-gr। lichen that poked up in slenc pointed miniature fingers that lool 